\title{
Recent trends and progress of Indian banking industry
}

\author{
Rubina Muazzam ${ }^{1, *}$, Pankaj Diwedi $^{2}$ \\ ${ }^{1}$ Research Scholar, ${ }^{2}$ Professor, School of Law \& Legal Affairs, Noida International University, Greater Noida, Uttar Pradesh, India \\ *Corresponding Author: Rubina Muazzam \\ Email: muazzam1953@gmail.com
}

\begin{abstract}
For the last five financial years, the study of balance sheet operations, profitability, capital adequacy, quality of property, regional deployment of bank loans, technical development, customer services and financial inclusion has been studied for Indian banking industry. It has been concluded that the emergence of universal or semi-universal banks in the development of banking sector in India is important, and therefore risk management and development of the appropriate regulatory system are the main challenge facing the banking industry in the near future.
\end{abstract}

Keywords: Profitability, Capital adequacy, Asset quality.

\section{Introduction}

Financial reforms were initiated in India around two decades back. These reforms were aimed at refining the performance of the banks and have thrown many challenges. The banks were set to line up their accounting standards with the International standards. The Indian banks have finally worked up to the competitive dynamics of the 'new' Indian market and are addressing the relevant issues to take on the multifarious challenges of globalization.

The secondary data on the Indian banking sector has been collected from annual reports and periodical papers of Reserve Bank of India. For the last five financial years, the study of balance sheet operations, profitability, capital adequacy, quality of property, regional deployment of bank loans, technical development, customer services and financial inclusion has been studied.

\section{Balance Sheet Operations}

Credit growth record was low due to a fall in demand and asset quality pressure. Due to the decline in industrial production, credit growth in India has declined in the last three years; Credit demand has declined as a result of leveraged corporate balance sheets and reduced capital expenditure. The banks are cautious in lending. During the financial year 2017, credit growth was $4.7 \%$, which was the lowest in over a decade.

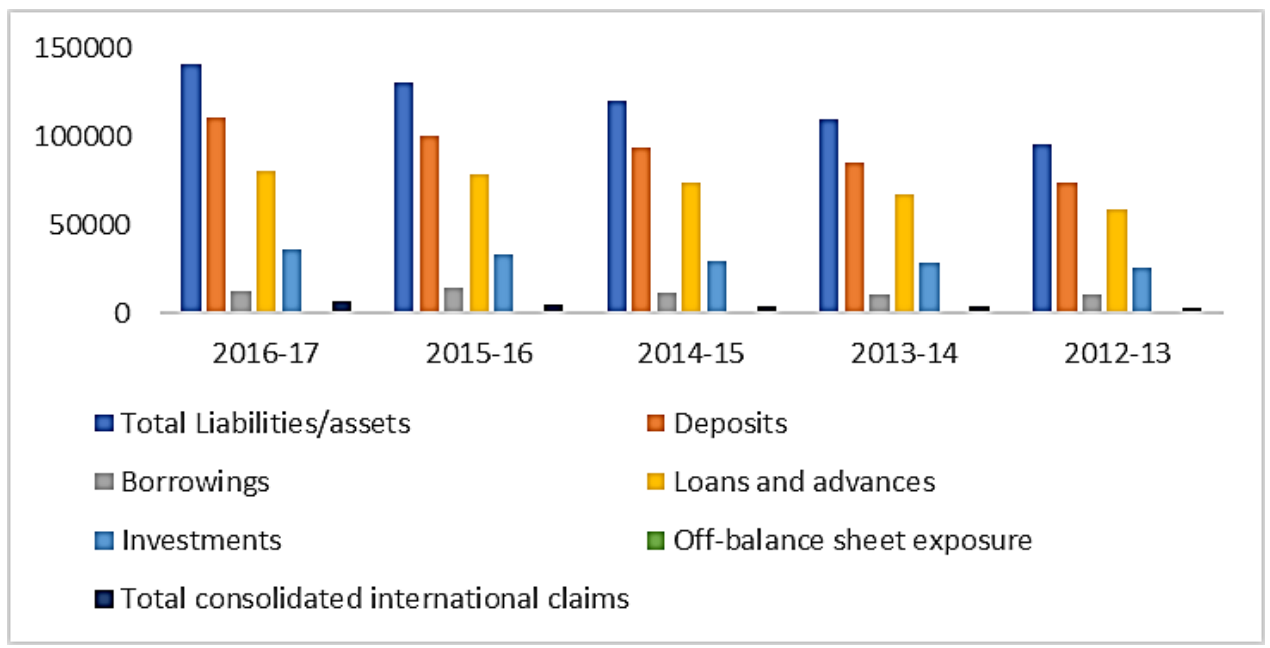

Fig. 1: Balance Sheet Operations during 2012-13 to 2016-17

\section{Profitability}

Deficit of assest quality has impacted the income growth and profitability of banks during the 2017 financial year. 35 banks studied by KRE ratings saw minor growth of $6 \%$ due to interest reversal on NPA accounts as well as lower credit growth. 


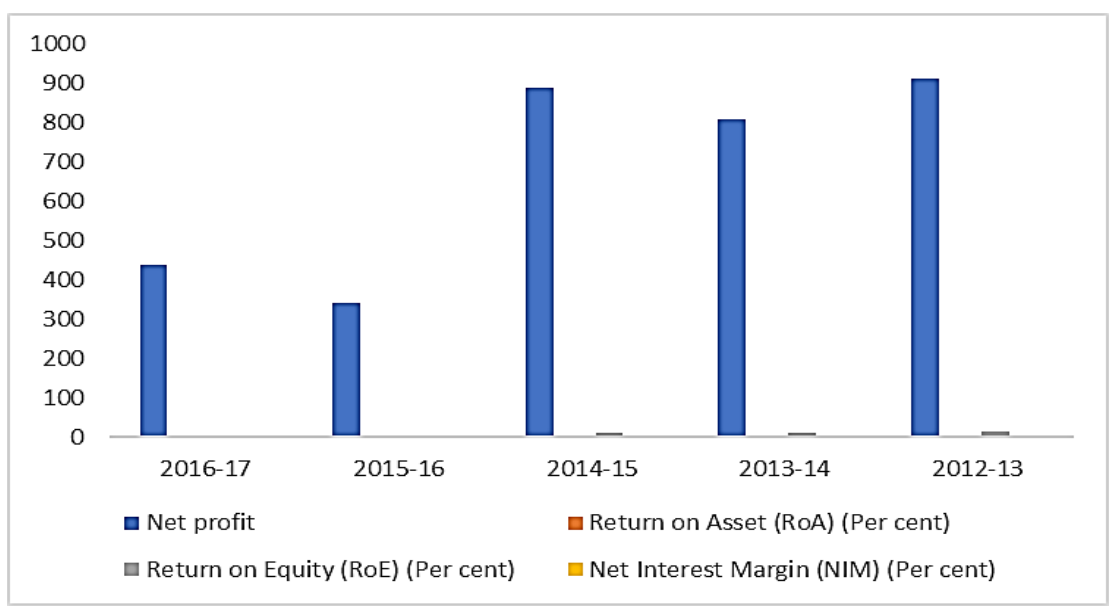

Fig. 2: Profitability during 2012-13 to 2016-17

\section{Capital Adequacy}

Public sector banks are the worst hit, compared to the end of June, their average capital adequacy ratio is declining $10.67 \%$ compared to $11.18 \%$ in March. The increase in nonexecuted assets has put pressure on their profitability, according to the data compiled by the Reserve Bank of India, due to the global economic downturn. Indian banks' capital adequacy ratio (CAR) has fallen to 13 per cent as of March 2014 from 13.88 per cent a year earlier, according to data compiled by the Reserve Bank of India.

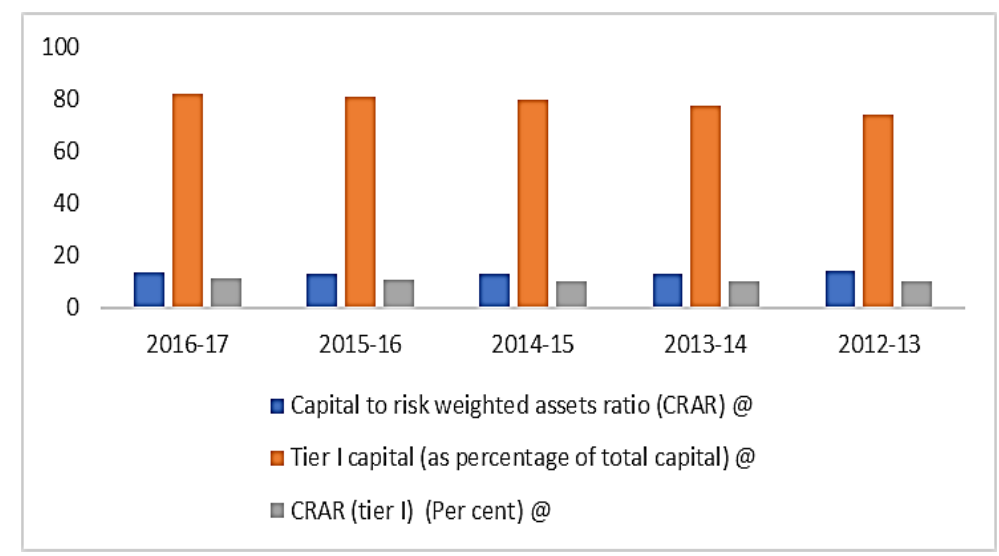

Fig. 3: Capital adequacy during 2012-13 to 2016-17

\section{Asset Quality}

The asset quality has been declining continuously in the last three years, with the sharp increase in NPAs. The private sector banks have seen high level of deterioration as compared to private sector banks. Gross NPA ratio of private banks have doubled from $2.11 \%$ (as on March, 2015) to 4.19\% (as on March 31, 2017).

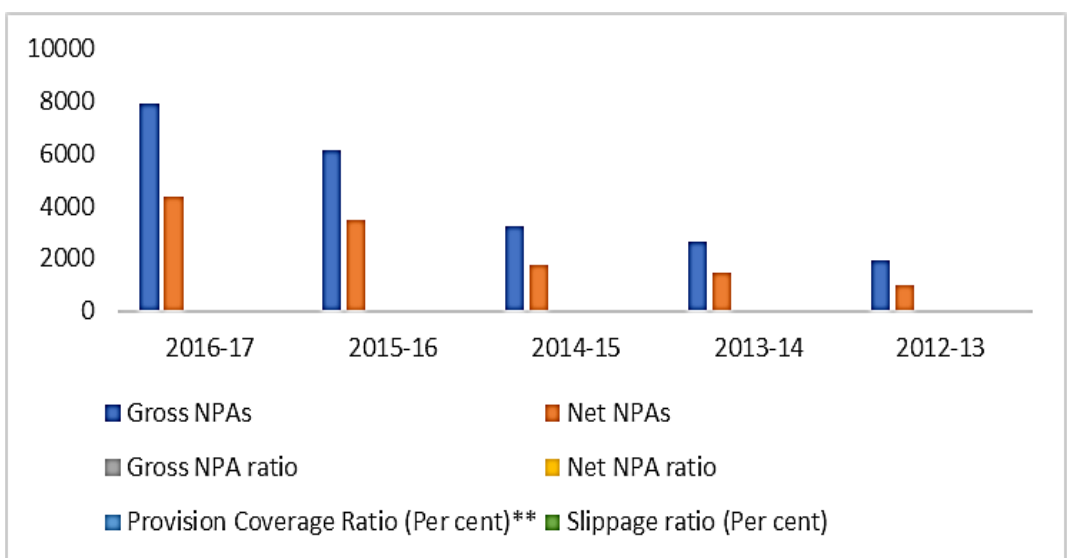

Fig. 4: Asset quality during 2012-13 to 2016-17 


\section{Sectoral Deployment of Bank Credit}

By the end of 2013, bank credit continued to expand at a healthy pace, generally at an annual rate of more than $15 \%$. But since the beginning of 2014, due to deployment of longstanding credits, it has been declining for a long time now. This recession clearly preceded the demonetization. In September 2016, a credit growth of approximately $11 \%$ fell to $3.3 \%$ in February 2017. Credit in service areas has remained volatile and the recession of bank credit directed to agriculture has been clear since April 2017. The credit to the industry was recovered firmly after the 2008-09 shock, as it was growing at an annual rate of $20-30 \%$ in the period of 2010-12. In November 2013, annual growth rate of less than $15 \%$ was clear for the first time and by the middle of 2016 , credit to the industry was flat or slightly negative.

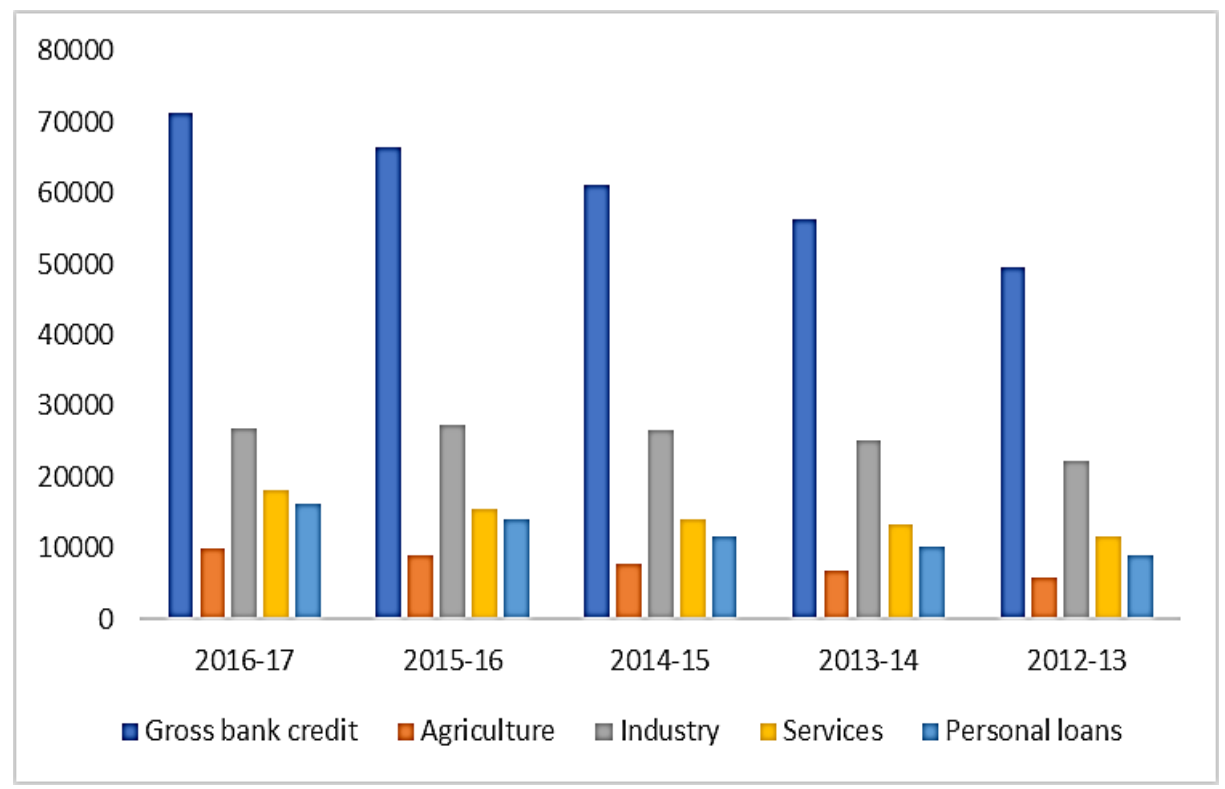

Fig. 5: Sectoral deployment of bank credit during 2012-13 to 2016-17

\section{Technological Development}

Banks have changed their operations towards universal banking, with the increasing use of technology and technology-based services offering alternative channels such as smart card, ATM, internet access, mobile and social banking. Banks have started deploying Core Banking, Human Resource Management (HRM) and Enterprise Risk (ERP) Management and Process Re-engineering etc. to improve their performance and productivity. Most banks are pushing cashless and paperless payment modes.

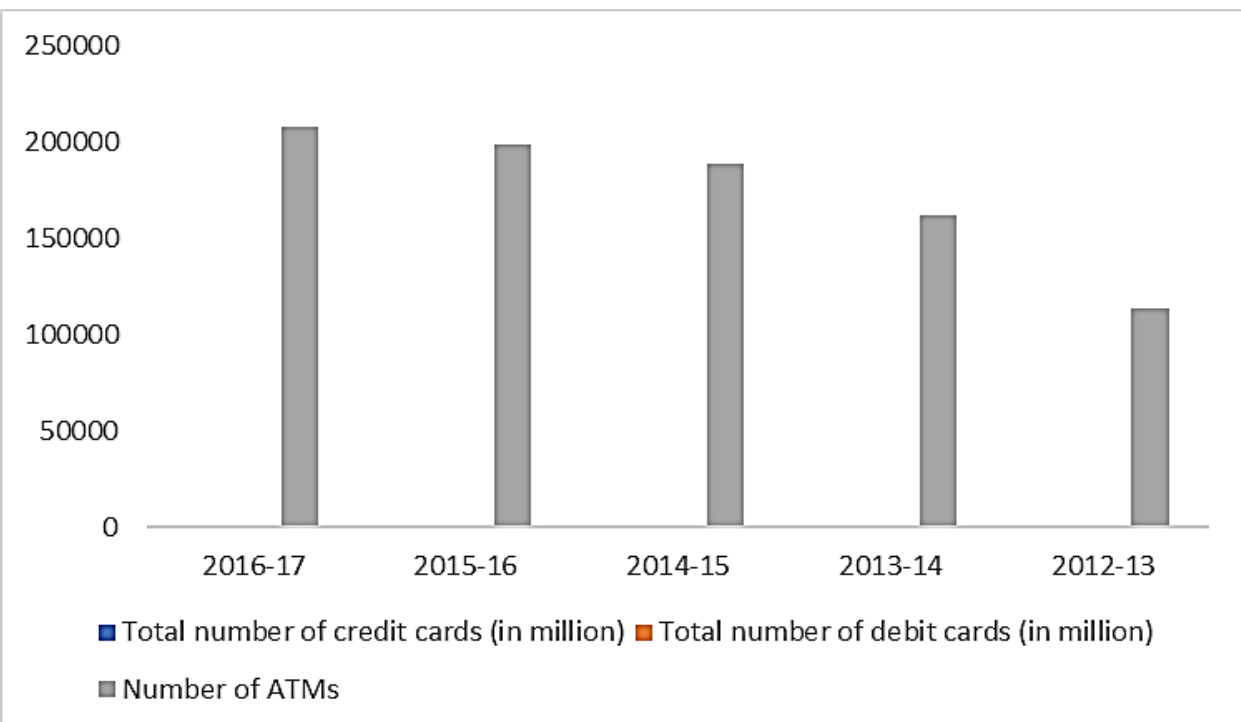

Fig. 6: Technological development during 2012-13 to 2016-17 


\section{Customer Services}

More and more customers are complaining to the Banking Ombudsman for poor services, failures to meet commitments, levy of fees without prior notice etc. In 201617, more than 20 offices of Banking Ombudsman received more than $1,36,000$ complaints in the country. According to a report released by the Reserve Bank of India (RBI), 92 percent of complaints had been settled. In the year 2016-17, the number of complaints increased by 27 percent, compared to the previous year's 21 percent. The increasing number of complaints indicates increasing awareness about the complaints system among the customers, but it can also indicate the quality of service in banks going down.

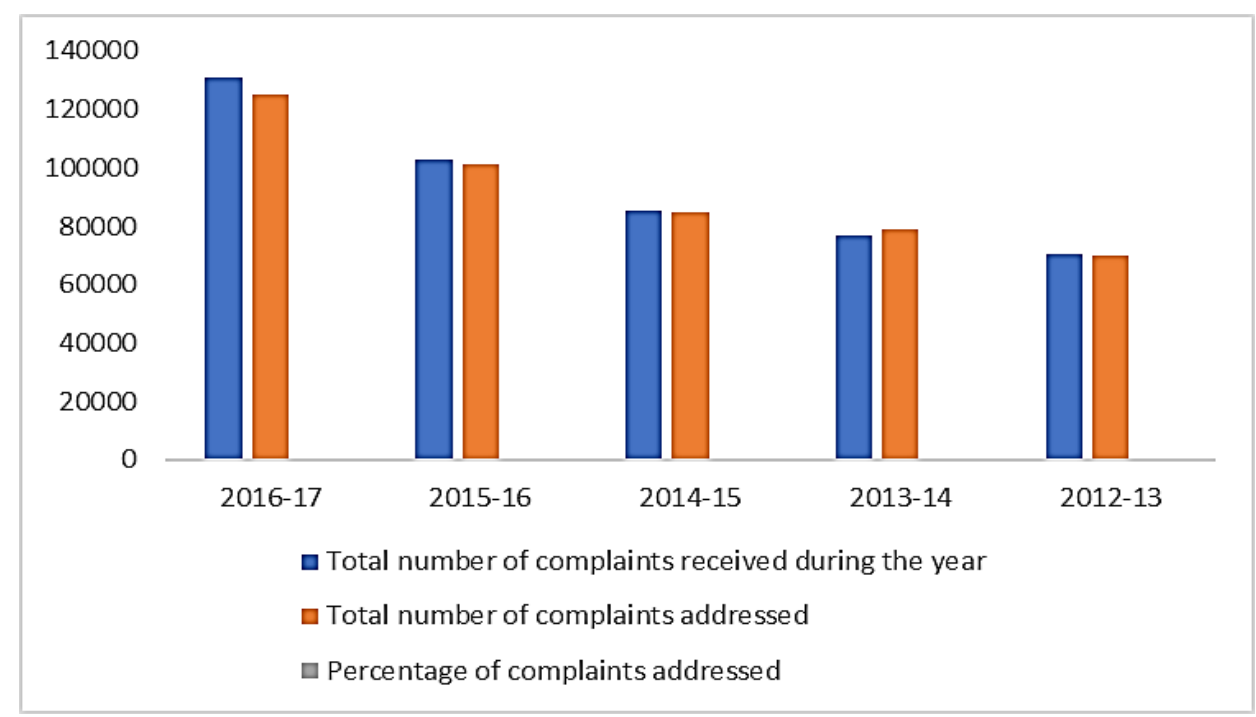

Fig. 7: Customer services during 2012-13 to 2016-17

\section{Financial Inclusion}

India's first financial inclusion index 2013 was started with the objective of becoming that important gauge and policy input. It is based on four dimensions - branch entry, deposit entry, credit entry and insurance entry.
The data shows a significant improvement in financial inclusion. The score has gone up from 50.1 in 2013 to 58.0 in 2006. The Jan Dhan Yojana has accounted for this improvement. About 600 million deposit accounts have been opened between 2013 and 2016. The Digital India initiative and payment banks have improved the access to formal financial services.

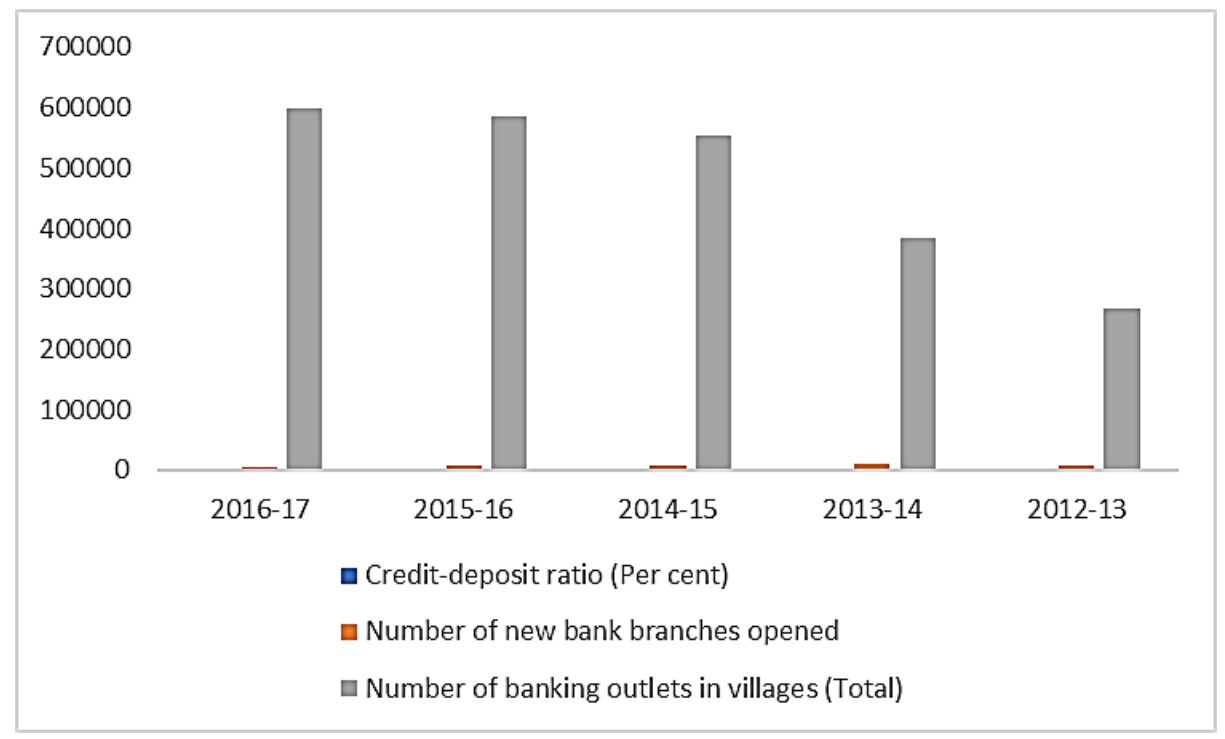

Fig. 8: Financial inclusion during 2012-13 to 2016-17

\section{Conclusion}

Increased spending on infrastructure, quick implementation of projects and continuation of reforms will further promote development. All these factors show that the banking sector of India has also been prepared for strong growth as the fast-growing business will turn for the credit requirements to banks. 
Also, the advancement in technology has brought mobile and internet banking services to the fore. The banking sector is pushing more customers to enhance their overall experience as well as provide better services to their customers and upgrade their technical infrastructure to give a competitive edge to the banks.

\section{Conflict of Interest: None.}

\section{References}

1. Media Reports, Press releases, Reserve Bank of India, Press Information Bureau.

2. Muraleedharan, D. (2014) - "Modern Banking: Theory and Practice", second Edition, PHI Learning Private Limited, Delhi.

3. Kumar, Sunil, Gulati, Rachita (2013)- "Dereggulation and Efficiency of Indian Banks.'

4. The Indian Banking Sector: Recent Developments, Growth and Prospects (2013).
5. Fernando, A, C. (2011)-" Business Environment"

6. Tiwar, Brajesh, Kumar. (2011)- "Changing Scenario of Indian Banking Industry."

7. www.rbi.org.in

8. En.wikipedia.org/wiki/Banking in India

9. Indian Banking-The engine for sustaining India's growth agenda, 5 ICC Banking summit, Kolkata, 18 May 2013: KPMG study report.

How to cite this article: Muazzam R, Diwedi P. Recent trends and progress of Indian banking industry. J Manag Res Anal. 2018;5(4):463-467. 